\title{
PENGARUH PENERAPAN GOOD CORPORATE GOVERNANCE TERHADAP NILAI PERUSAHAAN DENGAN IMPLEMENTASI CSR SEBAGAI VARIABEL PEMODERASI
}

\author{
Misbahul Munir \\ Eka Sevia Suryandari \\ Anik Mahmudah \\ Universitas Islam Negeri Maulana Malik Ibrahim Malang \\ Jalan Gajayana 50 Malang \\ E-mail:misbahul07@gmail.com
}

\begin{abstract}
Corporate Governance is a system that regulates and controls the company that is expected to provide and enhance the company's value to its shareholders. This study aims to determine the effect of the implementation of good corporate governance (GCG) to the value of state-owned banks companies listings in Indonesia stock exchange (IDX) with the implementation of corporate social responsibility (CSR) as a moderating variable. This research is a quantitative, analytical models using classical assumption test consists of a test heterokedastisitas, non-autocorrelation test and normality test, followed by analysis using regression analysis moderation. The results showed that, application of good corporate governance is proxied by Managerial Ownership (X1), Proportion of Independent Commissioner (X2), Audit Committee (X3), Independence of the Audit Committee (X4), Frequency of Audit Committee Meetings (X5) and the frequency of Board Meeting (X5) simultaneously significant effect on firm value (Tobin's Q). With the results of R Square of $61.1 \%$ means that the variable Tobin's Q (Y) in the six variables explained by the moderating variable of Corporate Social Responsibility (Z). While the remaining $38.9 \%$ is explained by other variables or independent variables outside the regression equation.
\end{abstract}

Keywords: good corporate governance, corporate sosial responsibility, variabel pemoderasi

Corporate Governance (CG) telah menjadi topik bahasan utama di bisnis global seiring dengan meningkatnya kompleksitas dan tekanan persaingan bisnis yang di hadapi perusahaan. Berbagai skandal korporasi/perusahaan besar, di antaranya Enron dan parmalat, menjadikan dunia internasional semakin mencurahkan perhatian terhadap CG. Skandal-skandal korporasi tersebut menunjukkan bahwa organ-organ perusahaan belum dapat melaksanakan fungsi,tugas, dan tanggung jawabnya secara baik. Di indonesia, terjadinya krisis ekonomi berisiko tinggi menimbulkan krisis dimensi sebagaimnaa pernah terjadi di tahun 1997. Resiko ini ditengarai karena ketidakoptimalan perusahaanperusahaan Indonesia dalam penerapan CG. (Warsono dan Amalia, 2009)

Nilai perusahaan yang tinggi dapat meningkatkan kemakmuran bagi para pemegang saham, sehingga para pemegang saham akan menginvestasikan modalnya kepada perusahaan tersebut (Haruman, 2008).
Nilai perusahaan dipengaruhi oleh banyak faktor, salah satunya adalah melalui tata kelola perusahaan yang baik atau Good Corporate Governance. Corporate governance merupakan suatu sistem yang mengatur dan mengendalikan perusahaan yang diharapkan dapat memberikan dan meningkatkan nilai perusahaan kepada para pemegang saham (Shleifer dan Vishny, 1997). Good Corporate Governance (GCG) dikatakan dapat menciptakan nilai tambah karena dengan menerapkan Good Corporate Governance, diharapkan perusahaan akan memiliki kinerja yang baik sehingga dapat menciptakan nilai tambah dan meningkatkan nilai perusahaan yang dapat memberikan keuntungan bagi para pemegang saham atau pemilik perusahaan. Secara lebih rinci, terminologi corporate governance dapat dipergunakan untuk menjelaskan peranan dan perilaku dari dewan direksi, dewan komisaris, pengurus perusahaan, dan para pemegang saham (Susanti, 2010). 
Corporate Social Responsibility (CSR) tidak lagi dihadapkan pada tanggung jawab yang berpijak pada single bottom line, yaitu nilai perusahaan (corporate value) yang direfleksikan dalam kondisi keuangannya (financial) saja. Tapi tanggung jawab perusahaan harus berpijak pada triple bottom lines. Di sini bottom lines lainnya selain finansial juga ada sosial dan lingkungan, karena kondisi keuangan saja tidak cukup menjamin nilai perusahaan tumbuh secara berkelanjutan (sustainable). Keberlanjutan perusahaan hanya akan terjamin apabila perusahaan memperhatikan dimensi sosial dan lingkungan hidup. Sudah menjadi fakta bagaimana resistensi masyarakat sekitar, di berbagai tempat dan waktu muncul ke permukaan terhadap perusahaan yang dianggap tidak memperhatikan aspek-aspek sosial, ekonomi dan lingkungan hidupnya (Kusumadilaga, 2010)

Dengan menerapkan Corporate Social Responsibility, perusahaan dapat menciptakan citra yang baik bagi perusahaan sehingga menimbulkan penilaian positif dari konsumen yang mampu meningkatkan loyalitas mereka terhadap produk yang dihasilkan perusahaan. Semakin baik pengungkapan Corporate Social Responsibility maka makin tinggi pula loyalitas konsumen yang akan berdampak pada peningkatan penjualan yang dapat memberikan nilai tambah bagi perusahaan. Selain itu perusahaan akan memperoleh legitimasi sosial dan memaksimalkan kekuatan keuangannya dalam jangka panjang melalui penerapan CSR (Kiroyan, 2006). Penerapan CSR ini selain akan menguatkan citra perusahaan, diharapkan akan memberi dampak positif pada pendapatan perusahaan pada umumnya sehingga investasi kepada perusahaan akan terjaga.

Selanjutnya, pengungkapan Corporate Social Responsibility dipilih sebagai variabel moderating karena kegiatan Corporate Social Responsibility merupakan bagian dari tata kelola perusahaan yang baik yang diharapkan mampu memperkuat hubungan Good Corporate Governance dengan nilai perusahaan. Akan tetapi tidak menutup kemungkinan hal tersebut hanya terjadi pada perusahaan-perusahaan tertentu karena kondisi tiap perusahaan berbeda, baik dari segi visi, misi, segmen pasar maupun manajemen perusahaan yang memungkinkan bahwa penerapan Corporate Social Responsibility maupun Good Corporate Governance justru tidak berpengaruh terhadap peningkatan nilai perusahaan.

Penelitian tentang Good Corporate Governance telah dilakukan beberapa penelitian diantaranya, penelitian dari Sam'ani (2008) hasil penelitian ini diperoleh hasil bahwa pengaruh corporate governance yang diproksi oleh aktivitas komisaris, ukuran dewan direksi, komite audit mempunyai hubungan yang positif dan signifikan terhadap kinerja perusahaan. Dari penelitian Wulandari (2006) didapatkan hasil bahwa pada indikator mekanisme corporate governance internal, hanya debt to equity yang signifikan berpengaruh positif terhadap kinerja perusahaan, sedangkan jumlah dewan direktur, proporsi dewan komisaris independen tidak signifikan berpengaruh positif terhadap kinerja perusahaan.

Dari penelitian Sam'ani (2008) dan Wulandari (2006) terdapat research gap antara keduanya. Dengan adanya research gap tersebut perlu diadakan penelitian lebih lanjut tentang pengaruh Good Corporate Governance terhadap kinerja perusahaan. Dalam penelitian ini peneliti menggunakan pengaruh Good Corporate Governance terhadap nilai perusahaan karena nilai perusahaan termasuk dalam kinerja perusahaan.

Dalam penelitian ini, peneliti mengambil kasus Badan Usaha Milik Negara (BUMN) khususnya pada sektor Perbankan sebagai objek penelitian. Pada sektor ini terdapat empat Bank BUMN. Namun dalam penelitian ini, peneliti hanya mengambil perusahaan BUMN yang telah listed di BEI (Bursa Efek Indonesia) untuk dijadikan sebagai objek penelitian yaitu terdiri dari Bank BRI, Bank BNI, Bank BTN dan Bank Mandiri. Selain itu, alasan pemilihan objek penelitian Bank BUMN yang telah listed di BEI oleh peneliti adalah karena pertimbangan bahwa perusahaan yang telah listed di BEI biasanya telah membuat anual report yang baik dan sesuai standar. Di samping itu tidak semua perusahaan membuat sustainability report, biasanya hanya perusahaan yang telah listed di BEI saja yang membuat laporan tersebut sehingga hal itu menjadi pertimbangan peneliti untuk memilih Bank BUMN yang telah listed di BEI sebagai objek penelitian.

\section{Konsep Dasar Good Corporate Governance $(G C G)$}

Dua teori utama yang terkait dengan corporate governance adalah stewardship theory dan agency theory. Stewardship theory dibangun di atas asumsi filosofis mengenai sifat manusia yakni bahwa manusia pada hakekatnya dapat dipercaya, mampu bertindak dengan penuh tanggung jawab, memiliki integritas dan kejujuran terhadap pihak lain. Inilah yang tersirat dalam hubungan fidusia yang dikehendaki para 
pemegang saham. Dengan kata lain, stewardship theory memandang manajemen sebagai dapat dipercaya untuk bertindak dengan sebaik-baiknya bagi kepentingan publik maupun stakeholder. Sementara itu, agency theory yang dikembangkan oleh Jensen, M.C., and W.H. Meckling (1976) memandang bahwa manajemen perusahaan sebagai "agents" bagi para pemegang saham, akan bertindak dengan penuh kesadaran bagi kepentingannya sendiri, bukan sebagai pihak yang arif dan bijaksana serta adil terhadap pemegang saham.

Dalam perkembangan selanjutnya, agency theory mendapat respon lebih luas karena dipandang lebih mencerminkan kenyataan yang ada. Berbagai pemikiran mengenai corporate governance berkembang dengan bertumpu pada agency theory di mana pengelolaan dilakukan dengan penuh kepatuhan kepada berbagai peraturan dan ketentuan yang berlaku. Good Corporate Governance (GCG) memiliki banyak definisi. Forum For Corporate Governance in Indonesia (FCGI) mendefinisikan corporate governance sebagai seperangkat peraturan yang menetapkan hubungan antara pemegang saham, pengurus, pihak kreditur, pemerintah, karyawan, serta para pemegang kepentingan intern dan ekstern lainnya sehubungan dengan hak-hak dan kewajiban mereka, atau dengan kata lain sistem yang mengarahkan dan mengendalikan perusahaan. Di kalangan pebisnis, secara umum, GCG diartikan sebagai tata kelola perusahaan. Good corporate governance (GCG) diartikan pula sebagai sistem yang mengatur dan mengendalikan perusahaan yang menciptakan nilai tambah (value added) untuk semua stakeholder (Monks, 2003). Ada dua hal yang ditekankan dalam konsep ini, pertama, pentingnya hak pemegang saham untuk memperoleh informasi dengan benar dan tepat pada waktunya. Kedua, kewajiban perusahaan untuk melakukan pengungkapan (disclosure) secara akurat, tepat waktu, transparan terhadap semua informasi kinerja perusahaan, kepemilikan, dan stakeholder.

Berdasarkan Pedoman Umum Good Corporate Governance Indonesia yang dikemukakan oleh Komite Nasional Kebijakan Governance (KNKG) (Zarkasyi, 2008) Good Corporate Governance memiliki prinsip-prinsip sebagai berikut: Pertama, Transparancy, untuk menjaga objektivitas dalam menjalankan bisnis, perusahaan harus menyediakan informasi relevan dengan cara yang mudah diakses dan dipahami oleh pemangku kepentingan. Perusahaan harus mengambil inisiatif untuk mengungkapkan bahwa tidak hanya masalah yang disyaratkan oleh peraturan perundang-undangan, tetapi juga hal yang penting untuk pengambilan keputusan oleh pemegang saham, kreditur, dan pemangku kepentingan lainnya.

Kedua, Accountability, perusahaan harus dapat mempertanggungjawabkan kinerjannya secara transparan dan wajar. Untuk itu perusahaan harus dikelola secara benar, terukur dan sesuai dengan kepentingan perusahaan dengan tetap memperhitungkan kepentingan pemegang saham dan pemangku kepentingan lain. Ketiga, Responsibility, perusahaan harus mematuhi peraturan perundang-undangan serta melaksanakan tanggungjawab terhadap masyarakat dan lingkungan sehingga dapat terpelihara kesinambungan usaha dalam jangka panjang dan mendapat pengakuan sebagai Good Corporate Governance. Pertanggungjawaban keuangan perusahaan juga perlu disampaikan dalam bentuk pengungkapan yang jujur dan wajar atas kondisi keuangan perusahaan. Sehingga pemegang saham dan stakeholder dapat mengambil keputusan yang tepat. Pelaporan keuangan yang benar dan akurat, juga akan mengahasilkan keakuratan dalam pembayaran zakat. Karena dari setiap keuntungan yang diperoleh muslim dalam kegiatan bisnisnya, setidaknya ada $2,5 \%$ yang menjadi hak kaum fakir miskin. Masalah zakat menjadi penting dalam perspektif Islam karena merupakan ciri diimplementasikannya Good Corporate Governance. Pengelolaan perusahaan yang baik tidak hanya bertujuan untuk memakmurkan manajemen dan pemegang saham, tetapi juga masyarakat di sekitar perusahaan tersebut khususnya kaum fakir dan miskin (Widiyanti, 2009).

Keempat, Independency, untuk melancarkan pelaksanaan Good Corporate Governance, perusahaan harus dikelola secara independen sehingga masing-masing organ perusahaan tidak saling mendominasi dan dapat diintervensi oleh pihak lain. Independen merupakan karakter manusia yang bijak (ulul albab) yang dalam al-Quran disebutkan sebanyak 16 kali, yang di antara karakternya adalah "Mereka yang mampu menyerap informasi (mendengar perkataan) dan mengambil keputusan (mengikuti) yang terbaik (sesuai dengan nuraninya tanpa tekanan pihak manapun). Keadaan ini adalah keadaan di mana perusahaan dikelola secara profesional tanpa benturan kepentingan dan pengaruh/tekanan dari pihak manajemen yang tidak sesuai dengan peraturan dan perundangan-undangan yang berlaku dan prinsipprinsip korporasi yang sehat. 


\section{Konsep Dasar Corporate Social Responsibility (CSR)}

Corporate Social Responsibility adalah tanggungjawab perusahaan terhadap masyarakat di luar tanggungjawab ekonomis. Jika berbicara tanggungjawab perusahaan, yang dimaksud adalah kegiatankegiatan yang dilakukan perusahaan demi suatu tujuan sosial dengan tidak memperhitungkan untung dan rugi (Simorangkir, 2003). Corporate Social Responsibility diartikan sebagai mekanisme bagi suatu perusahaan untuk secara sukarela mengintegrasikan perhatian terhadap lingkungan sosial ke dalam operasinya dan interaksinya dengan stakeholder, yang melebihi tanggungjawab sosial di bidang hukum.

Konsep tanggungjawab sosial perusahaan telah mulai dikenal sejak tahun 1979 yang secara umum diartikan sebagai kumpulan kebijakan dan praktek yang berhubungan dengan stakeholder, nilai-nilai pemenuhan hukum, penghargaan masyarakat terhadap lingkungan serta komitmen dunia usaha. Pearce dan Robinson (2007) menyebutkan ada sepuluh pihak yang mempunyai kepentingan terhadap perusahaan yang masing-masing mempunyai kepentingan berbeda dan cara pandang yang berbeda terhadap perusahaan. Kesepuluh pihak yang dimaksud adalah stockholders, creditor, employees, customers, suppliers, governments, unions, competitors, local communities, general public.

Pearce dan Robinson (2007) dalam Budiartha (2008) juga membagi tanggung jawab perusahaan menjadi empat bagian antara lain: economic responsibility, legal responsibility, ethical responsibility, discretionary responsibility, Secara ekonomi tanggung jawab perusahaan adalah untuk menghasilkan barang dan jasa kepada masyarakat dengan reasonable cost dan memberikan keuntungan kepada perusahaan. Dengan menghasilkan barang dan jasa maka perusahaan diharapkan memberikan pekarjaan yang produktif terhadap masyarakat sekitarnya, menyumbangkan sebagian keuntungan dalam bentuk pajak kepada pemerintah.

Legal responsibility, di mana pun tempat operasi suatu perusahaan tidak akan dapat melepaskan diri dari aturan dan perundang-undangan yang berlaku yang mengatur tentang kegiatan bisnis. Peraturan tersebut terutama yang terkait dengan usaha untuk mengontrol perubahan lingkungan dan keamanan konsumen. Ethical responsibility, perusahaan didirikan tidak hanya berperilaku legal secara hukum, tetapi juga memiliki etika. Sering kali terjadi perbedaan antara legal dan etika. Bisa jadi sesuatu yang dikatakan legal, tetapi tidak beretika. Discretionary responsibility, tanggung jawab ini sifatnya sukarela seperti public relation activities, menjadi warga negara yang baik, dan tanggung jawab perusahaan lainnya. Melalui public relation yang baik manajer mencoba untuk meningkatkan kesan terhadap perusahaan, barang dan jasa yang dihasilkan.

\section{METODE}

Penelitian ini bertempat di Pojok Bursa Efek Indonesia (BEI) Universitas Islam Negeri Maulana Malik Ibrahim Malang Jalan Gajayana 50 Malang, atau dengan mengunjungi website masing-masing perusahaan yang bersangkutan. Karena data yang dibutuhkan dalam penelitian semua sudah dipublikasikan oleh perusahaan. Penelitian ini menggunakan jenis penelitian kuantitatif deskriptif. Penelitian kuantitatif adalah penelitian dengan menggunakan model matematik, statistik atau komputer. Sedangkan deskriptif adalah metode penelitian yang ditujukan untuk menggambarkan fenomena yang ada (Sukmadinata, 2007). Populasi dalam penelitian ini adalah seluruh perusahaan perbankan yang listing di Bursa Efek Indonesia.

Metode pemilihan sampel yang digunakan dalam penelitian ini adalah metode purposive judment sampling yaitu tipe pemilihan sampel secara tidak acak yang informasinya diperoleh dengan menggunakan pertimbangan tertentu. Adapun kriteria pemilihan sampel dalam penelitian ini adalah: (1) Perusahaan perusahaan perbankan yang terdaftar di BEI dan merupakan Bank BUMN, (2) Perusahaan memiliki laporan dan data keuangan tahun 2011-2012 (3) Perusahaan perbankan yang mengungkapkan CSR di dalam annual report-nya. Berdasarkan kriteria di atas maka diperoleh sampel penelitian sebagai berikut: Bank Rakyat Indonesia (BRI), Bank Negara Indonesia (BNI), Bank Tabungan Negara (BTN) dan Bank Mandiri. Dalam penelitian ini digunakan beberapa variabel untuk praktek corporate governance yaitu: Kepemilikan Manajerial (X1), Proporsi Komisaris Independen (X2), Komite Audit (X3), Independensi Komite Audit (X4), Frekuensi Rapat Komite Audit (X5), Frekuensi Rapat Dewan Komisaris (X6), dan nilai perusahaan, sebagai variabel dependen $(\mathrm{Y})$

\section{HASIL}

Variabel Kepemilikan manajerial (X1) memiliki nilai signifikansi t 0.243 lebih besar dari alpha $0.1 \mathrm{ini}$ berarti $\mathrm{H} 1$ ditolak, dapat disimpulkan bahwa variabel Proporsi Komisaris Independen (X1) secara statistik 
berpengaruh negatif tidak signifikan terhadap nilai perusahaan. Variabel Proporsi Komisaris Independen (X2) memiliki nilai signifikansi t 0.024 lebih kecil dari alpha 0.1 ini berarti $\mathrm{H} 2$ diterima, dapat disimpulkan bahwa variabel Komisaris Independen (X2) secara statistik berpengaruh positif dan signifikan terhadap nilai perusahaan. Variabel Komite Audit (X3) memiliki nilai signifikansi t 0.133 lebih besar dari alpha 0.01 ini berarti $\mathrm{H} 3$ ditolak, dapat disimpulkan bahwa variabel Komite Audit (X3) secara statistik berpengaruh positif tidak signifikan terhadap nilai perusahaan.

Variabel Independensi Komite Audit (X4) memiliki nilai signifikansi t 0.096 lebih kecil dari alpha 0.1 ini berarti $\mathrm{H} 4$ diterima, dapat disimpulkan bahwa variabel Independensi Komite Audit (X4) secara statistik berpengaruh positif dan signifikan terhadap nilai perusahaan. Variabel Frekuensi Rapat Komite Audit (X5) memiliki nilai signifikansi t 0.171 lebih besar dari alpha 0.1 ini berarti H5 ditolak, dapat disimpulkan bahwa variabel Frekuensi Rapat Komite Audit (X5) secara statistik berpengaruh negatif tidak signifikan terhadap nilai perusahaan. Variabel Frekuensi Rapat Dewan Komisaris (X6) memiliki nilai Signifikansi t 0.619 lebih besar dari alpha 0.1 ini berarti H6 Ditolak, dapat disimpulkan bahwa variabel Frekuensi Rapat Dewan Komisaris (X6) secara statistik berpengaruh positif tidak signifikan.

\section{PEMBAHASAN}

\section{Pengaruh Kepemilikan Manajerial terhadap Nilai Perusahaan}

Berdasarkan hasil pengujian variabel proporsi komisaris independen terhadap nilai perusahaan, dapat diketahui bahwa variabel Kepemilikan Manajerial berpengaruh negatif terhadap nilai perusahaan. Oleh karena itu, hipotesis (H1) "Kepemilikan manajerial berpengaruh positif terhadap nilai perusahaan" di tolak. Kepemilikan Manajerial mempunyai arah negatif dan tidak signifikan terhadap nilai perusahaan. Hal ini sesuai dengan teori Jensen (2001) mengungkapkan bahwa untuk mencapai tujuan perusahaan dan meningkatkan nilai perusahaan dalam jangka panjang manajer dituntut untuk membuat keputusan yang memperhitungkan kepentingan semua stakeholder, di mana para stakeholder ini masing-masing memiliki kepentingan sendiri. Terkait dengan perbedaan kepentingan ini, manajer perusahaan cenderung mengutamakan kepentingannya yang tujuannya bertentangan dengan tujuan perusahaan, sehingga nilai perusahaan justru akan menurun karena kepentingan pribadi manajer tersebut.

\section{Pengaruh Proporsi Komisaris Independen terhadap Nilai Perusahaan}

Penelitian ini menunjukkan bahwa variabel proporsi komisaris independen memiliki hubungan arah positif dan signifikan. Hal ini berarti variabel proporsi komisaris independen berpengaruh terhadap nilai perusahaan. Dengan demikian hipotesis kedua yang diajukan "proporsi komisaris independen berpengaruh terhadap nilai perusahaan" diterima. Penemuan ini konsisten dengan penelitian Kusumadilaga (2010) dan Wulandari (2006). Sesuai dengan teori agensi, fungsi dewan komisaris berperan mengurangi terjadinya agency cost yang tinggi, dengan adanya peningkatan pengawasan dan transparansi akan berdampak pada penurunan information asymmetry dan impilikasinya monitoring cost pun akan mengalami penurunan, sehingga efisiensi perusahaan juga dapat terwujud. Hal ini didasarkan pada logika ketika manajemen (agen) diawasi secara ketat oleh komisaris, mereka akan berupaya untuk menunjukkan kepada komisaris (principal) bahwa mereka tidak akan menyalahgunakan kewenangan yang diberikan, dan manajer akan berbuat demi kebaikan perusahaan. Kesadaran hal memunculkan upaya (efforts) dari manajemen agar mereka dipercaya oleh principal.

\section{Pengaruh Komite Audit terhadap Nilai Perusahaan}

Penelitian ini menunjukkan bahwa variabel komite audit memiliki hubungan arah positif dan tidak signifikan. Hal ini berarti variabel komite audit tidak berpengaruh terhadap nilai perusahaan. Dengan demikian hipotesis ketiga yang diajukan "komite audit berpengaruh terhadap nilai perusahaan" ditolak. Hasil penelitian ini mendukung penelitian Dewayanto (2010), jadi berapapun jumlah komite audit tidak mempengaruhi dari nilai perusahaan karena komite audit hanya sebagai pengawas yang efektif terhadap manajemen perusahaan. Tidak berpengaruh terhadap nilai perusahaan yang dicerminkan dengan naiknya harga saham perusahaan.

\section{Pengaruh Independensi Komite Audit terhadap Nilai Perusahaan}

Dalam penelitian ini, indepedensi komite audit adalah komposisi komite audit independen terhadap jumlah total anggota komite audit. Dari hasil pengujian 
yang telah dilakukan, dapat diketahui jika variabel ini berpengaruh signifikan terhadap nilai perusahaan. Dengan demikian hipotesis keempat yang menyatakan bahwa "indepedensi komite audit berpengaruh positif terhadap nilai perusahaan" diterima. Jadi, semakin banyak komite audit independen maka nilai perusahaan semakin baik juga. Hasil ini sesuai dengan penelitian Sam' ani (2008) yang menemukan peranan komite audit dalam meningkatkan kinerja perusahaan, terutama dari aspek pengendalian. Hal ini menunjukkan, komite audit mampu menjaga independensinya dengan baik, sehingga proses pengawasan terhadap audit dapat dilakukan secara menyeluruh dan lebih efektif.

\section{Pengaruh Frekuensi Rapat Komite Audit terhadap Nilai Perusahaan}

Berdasarkan pengujian variabel frekuensi rapat komite audit terhadap nilai perusahaan, ditemukan bahwa frekuensi rapat komite audit tidak signifikan dengan arah yang positif, sehingga hipotesis ke empat yang menyebutkan bahwa "frekuensi rapat komite audit berpengaruh positif terhadap nilai perusahaan" ditolak. Dengan demikian dapat disimpukan semakin banyak jumlah rapat yang dilakukan komite audit maka nilai perusahaan belum tentu bagus. Penelitian ini menyatakan bahwa frekuensi rapat komite audit berpengaruh terhadap nilai perusahaan. Berdasarkan hasil penelitian ini dapat diketahui jika semakin sering komite audit mengadakan rapat dapat meningkatkan kinerja dari perusahaan sehingga nilai perusahaan belum tentu semakin baik juga. Hal ini dikarenakan, pertemuan yang terlalu sering bukan berarti nilai perusahaan semakin bagus namun pertemuan itu justru membuang waktu dalam peningkatan kinerja perusahaan dikarenakan komite audit terlalu sering melakukan rapat.

\section{Pengaruh Frekuensi Rapat Dewan Komisaris terhadap Nilai Perusahaan}

Berdasarkan pengujian variabel frekuensi rapat dewan komisaris terhadap nilai perusahaan, di temukan bahwa frekuensi rapat dewan komisaris tidak signifikan dengan arah yang positif, sehingga hipotesis ke enam yang menyebutkan bahwa "frekuensi rapat dewan komisaris berpengaruh positif terhadap nilai perusahaan" ditolak. Dengan demikian dapat disimpulkan semakin banyak jumlah rapat yang dilakukan dewan komisaris maka nilai perusahaan belum tentu baik, karena tersitanya waktu yang disisihkan untuk rapat maka kinerja dari dewan komisaris berkurang sehingga nilai perusahaan justru akan menurun.

\section{KESIMPULAN DAN SARAN}

\section{Kesimpulan}

Dalam konsep Good Corporate Governance $(G C G)$ terdapat empat komponen utama yang harus dipenuhi oleh perusahaan untuk meningkatkan kualitas laporan keuangan dan untuk mengurangi aktifitas menyimpang terhadap laporan keuangan, yaitu transparancy, accountability, responsibility, dan fairness. Perusahaan harus memenuhi keempat komponen tersebut agar nilai perusahaan tersebut akan baik, sehingga para investor bisa tertarik investasi di perusahaan tersebut. Dalam perusahaan BUMN diwajibkan menerapkan tata kelola perusahaan Good Corporate Governance (GCG) ini.

Penelitian ini dilakukan untuk menguji pengaruh karakteristik Good Corporate Governance (GCG) terhadap nilai perusahaan yang dilihat dari kepemilikan manajerial, proporsi komisaris independen, komite audit, independensi komite audit, frekuensi rapat komite audit, frekuensi rapat komite audit. Hasil penelitian ini menunjukan keenam karakteristik Corporate Governance berpengaruh secara signifikan terhadap nilai perusahaan. Faktor kepemilikan manajerial, proporsi komisaris independen, komite audit, independensi komite audit, frekuensi rapat komite audit, frekuensi rapat komite audit secara bersama-sama mempengaruhi nilai perusahaan sebesar $61,1 \%$ dengan demikian faktor-faktor karakteristik Corporate Governance masih belum sepenuhnya dapat meningkatkan pengawasan yang baik untuk mendorong kinerja yang baik sehingga nilai perusahaan juga akan baik.

Corporate Social Responsibility (CSR) dapat memoderasi hubungan Good Corporate Governance dengan hasil nilai koefisien standardized beta bahwa pengaruh semua variabel independen yaitu kepemilikan manajerial, proporsi komisaris independen, komite audit, independensi komite audit, frekuensi rapat komite audit, frekuensi rapat komite audit pada variabel Tobin's $\mathrm{Q}(\mathrm{Y})$ yang mengalami peningkatan dengan adanya moderasi CSR (Z) menunjukkan bahwa variabel moderasi CSR (Z) dapat meningkatkan besarnya pengaruh semua variabel independen yaitu kepemilikan manajerial, proporsi komisaris independen, komite audit, independensi komite audit, frekuensi rapat komite audit, frekuensi rapat komite audit pada variabel Tobin's Q (Y). 


\section{Saran}

Penelitian ini memiliki keterbatasan dan saran yang dapat menjadi arah penelitian yang akan datang antara lain; jumlah sampel hanya 4 perusahaan bank BUMN saja, penelitian selanjutnya disarankan untuk menambah sampel perusahaan yang menerapkan sistem tata kelola Good Corporate Governance $(G C G)$, agar kesimpulan yang dihasilkan dari penelitian tersebut memiliki cakupan yang lebih luas. Selain itu, periode pengamatan 5 tahun yaitu pada tahun 2008 sampai 2012 saja sehingga masih belum dapat sepenuhnya menggambarkan kondisi nilai perusahaan. Penelitian selanjutnya diharapkan memperluas periode penelitian. Penelitian selanjutnya sebaiknya mempertimbangkan menggunakan variabel lain di luar variabel yang digunakan dalam penelitian ini mengingat adanya variabel lain yang juga mempengaruhi nilai perusahaan.

\section{DAFTAR RUJUKAN}

Budhiarta, K. 2008. Cara Pandang Undang-Undang RI no.40 Tahun 2007 dan Undang-Undang RI no.17 tahun 2000 Terhadap Corporate Social Responsibility. Jurnal Fakultas Ekonomi Udayana

Dewayanto, T., dan Irmalasari. 2010. Pengaruh Mekanisme Good Corporate Governance terhadap Kinerja Perbankan Nasional (Studi pada Perusahaan perbankan yang Terdaftar di Bursa Efek Indonesia Periode 2006-2008).

Haruman, T. 2008. Pengaruh Struktur Kepemilikan terhadap Keputusan Keuangan dan Nilai Perusahaan. Simposium Nasional Akuntansi XI, Pontianak.

Jensen, M.C., and W.H. Meckling. 1976. "Theory of The Firm: Manajerial Behaviour, Agency Cost, and Ownership Structure". Journal of Financial and Economics, 3, 305-360.

Kiroyan, N. 2006." Good Corporate Governance (GCG) dan Corporate Social Responsibility (CSR) Adakah Kaitan di Antara Keduanya?" Economics Business Accounting Review. Ed. September-Desember: 4558.
Kusumadilaga, R. 2010. Pengaruh Corporate Social Responsibility terhadap Nilai Perusahaan dengan Profitabilitas sebagai Variabel Moderating (Studi Empiris pada Perusahaan Manufaktur yang Terdaftar di Bursa Efek Indonesia). Skripsi. Universitas Diponegoro Semarang.

Monks, R., Minow, N. 1996. ” Watching the Watchers: Corporate Governance for the $21^{\text {st }}$ Century", Cambridge, Blackwell.

Pearce II. John, A., and Robinson, Richard, B., Jr. 2007. Strategic Management, Formulation, Implementation and Control. Tenth Edition. Boston: McGrawHill.

Sam'ani. 2008. Pengaruh Good Corporate Governance dan Leverage terhadap Kinerja Keuangan pada Perbankan yang Terdaftar di Bursa Efek Indonesia (BEI) Tahun 2004-2007. Tesis. Universitas Diponegoro Semarang.

Shleifer, A., dan R.W. Vishny. 1997. A Survey of Corporate Governance. The Journal of Finance. 52 (2):737-783.

Simorangkir. 2003. Etika: Bisnis, Jabatan dan Perbankan. Jakarta: Rineka Cipta.

Sukmadinata, N.S. 2007. Metode Penelitian Pendidikan. Bandung: PT Remaja Rosdakarya

Susanti, R. 2010. Analisis Faktor-Faktor yang Berpengaruh terhadap Nilai Perusahaan (Studi Kasus pada Perusahaan Go Public yang Listed Tahun 20052008). Skripsi. Universitas Diponegoro Semarang.

Warsono, S., \& Fitri, A. 2009.Corporate Governance Concept and Model.Yogyakarta: Center for Good Corporate Governance FE UGM.

Widiyanti, N.W. 2009. Corporate Governance dalam Pandangan Islam: Sebuah Konsep Altertantif dalam Penerapan Good Corporate Governance. Jurnal Akuntansi Universitas Jember, 7 (2):104-111.

Wulandari, N. 2006. Pengaruh Indikator Mekanisme Corporate Governance terhadap Kinerja Perusahaan Publik di Indonesia. Jurnal Vol. 1 No. 2.

Zarkasyi, M.W. 2008. Good Corporate Governance Pada Badan Usaha Manufaktur Perbankan dan Jasa Keuangan Lainnya. Bandung: Penerbit Alfabeta. 